\title{
2016 International Year of Global Understanding: Building bridges between global thinking and local actions
}

\author{
Benno Werlen ${ }^{1}$, Luiz Osterbeek ${ }^{2}$ and M. H. Henriques ${ }^{3}$ \\ ${ }^{1}$ Friedrich-Schiller- University of Jena, Executive Director of IYGU. E-mail: benno.werlen@gmail.com \\ ${ }^{2}$ Geosciences Centre and Instituto Politécnico de Tomar, Secretary General of the International Council for Philosophy and Human Sciences \\ and Scientific Board of the IYGU.E-mail: loost@ipt.pt \\ ${ }^{3}$ Geosciences Centre and Department of Earth Sciences, University of Coimbra (Polo II), President of the Executive Board of the IYGU \\ Reference Action Centre in Portugal. E-mail: hhenriq@dct.uc.pt
}

(Received: 21/12/2015; Accepted: 12/04/2016)

DOI:10.18814/epiiugs/2016/v39i4/103894

2016 is the International Year of Global Understanding (IYGU). The IYGU declared by the three leading global sciences organizations of the natural, social, and human sciences recognizes that global social, cultural and climate changes require a global level of understanding. In this paper the basic IYGU guidelines are discussed, as well as the goals and action areas of this ambitious initiative. The topical framework and the outreach program are also described, as well as coordination, partners and organizational structure. The IYGU aims to bridge the gap in awareness between local actions and global effects, and will provide information on culturally differentiated ways to achieve global sustainability. By doing so, the IYGU will help in developing a new geographical imagination for a radically changing world.

\section{Introduction}

Every day, we experience that globalization has brought and continues to bring far-flung places and people into ever-closer contact. New kinds of supra-national communities are emerging at an accelerating pace. At the same time, these trends do not efface the local. Globalization is also associated with a marked re-affirmation of places and regions as distinctive forums of human action. In one way or the other, all human actions remain regionally and locally contextualized.

The globalization (Albrow, 1996) and acceleration (Rosa, 2015) of everyday life is bringing about a new world order that not only involves heightened awareness of the Earth and its inhabitants as a culturally integrated social-ecological system, but also the emergence of an integrated global socio-economic reality (Stehr, 2016). Although anthropic impacts over the environment are a long historical process
(Cruz et al., 1999; Almeida et al., 2014), the challenges that the world's climate, ecosystems, biodiversity, economic order, and socio-cultural well-being face are intensifying, which means that those who are already the most vulnerable will bear the brunt of the impacts. While globalization allowed for unprecedented growth and retreat of poverty, social divides, environmental stress and impending threats to cultural diversity paved the way for also growing risks of multiple disruptions (Beck, 2016).

Global environmental change research has produced - as documented in the latest IPCC report- unambiguous scientific insights into Earth's system processes. Nevertheless, these insights are rarely translated into effective policies. In other words, knowledge of the existence and severity of a problem only rarely leads to changes in actions - especially with regard to everyday activities, which, more often than not, are deeply ingrained, habitual routines. Assuming that these (everyday) actions are rooted in culturally specific values, norms, beliefs, and attitudes that we have learned and acquired throughout our socialization and education programs (O'Brien et al., 2013) directed at changing ecologically harmful habits would first of all require a deeper knowledge of their socio-cultural contexts. In turn, this would enable an improved social and cultural acceptance of scientific knowledge and would help to establish culturally differentiated paths to global sustainability (Osterbeek et al., 2013; Werlen, 2015a).

The International Year of Global Understanding (IYGU) therefore acknowledges that societies and cultures determine the ways we live with and shape our everyday life contexts (Fig. 1). The IYGU addresses issues pertaining to the ways we live in an increasingly globalized world, and endeavors to view the transformation of nature from a global sustainability perspective - the objective the IYGU wishes to achieve for the sake of future generations. In this sense it fosters a new paradigm of sustainability, which is rooted in an inextricably both cultural and scientific approach through education and agency.

True transdisciplinary research appears to be a primary necessity to achieve this objective (Bunders et al., 2015; Werlen 2015b). This would mean overcoming the established divide between the natural 


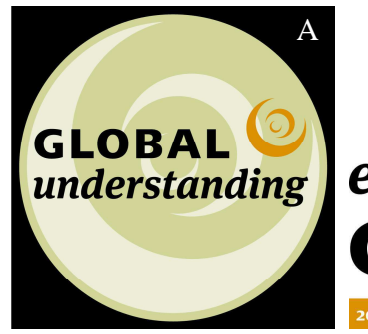

Figure 1. The official logo of the International Year of Global Understanding in English (A) and Portuguese versions (B).

and the human and social sciences, and integrating natural and social and humanistic scientific knowledge with non-scientific and nonWestern forms of knowledge. The global competence framework that such an undertaking needs to develop, should endeavor to generate effective bottom-up solutions to global socio-ecological problems, thus complementing existing top-down measures.

\section{Points of Departure and Goals}

The basic IYGU guidelines are supported by several relevant statements by referent personalities from different knowledge domains (Table 1) and can be summarized as follows:

1. Thinking globally and acting locally presupposes global understanding. In order to achieve global sustainability, we need to bridge the gap in awareness between local actions and global effects. Herein lays the ultimate significance of a program for the promotion of global understanding.

2. Humankind is confronted with unprecedented situations. The world's climate, ecosystems, biodiversity, economic system, and socio-cultural well-being are at stake. Those already most vulnerable will bear the brunt of the impacts, making it increasingly difficult to meet the UN Post-2015 Development Agenda.

3. Global environmental change research has produced scientific insights into earth system processes that are rarely translated into effective policies. We need to deepen our knowledge of sociocultural contexts.

4. Genuine transdisciplinary research is a first-order necessity. In order to achieve this, we need to overcome the established divide between the natural, the human and the social sciences. Natural and social scientific knowledge have to be integrated with nonscientific and non-Western forms of knowledge to develop a global competence framework.

5. It is imperative that the gap between global problems and national, regional, and local behavior and decision-making be bridged. Effective solutions must be based on bottom-up decisions and actions, and should be complemented by top-down measures when necessary.

These guidelines aim to meet several goals to be accomplished focusing actions in different social domains, as described in the following section.

\section{Objectives and Action Areas}

The objectives of the IYGU complement those of the Future Earth initiative established by the International Council of Science (ICSU) and the International Social Science Council (ISSC).

The IYGU has five objectives:

1. Promote the comprehensive notion of Global Understanding and increase awareness of the natural and cultural embeddedness of all human action.

2. Contribute to changing ecologically harmful habits by designing culturally differentiated, exemplary alternative models of core

Table 1: Reference personalities and their vision regarding the importance of an International Year of Global Understanding (quotes prepared by the authors for IYGU presentation).

\begin{tabular}{|c|c|}
\hline $\begin{array}{l}\text { Dr. h.c. Eliezer Batista (Brazil) } \\
\text { Key Initiator of the Rio Summit } 1992 \text { and founder } \\
\text { of the World Business Council for Sustainable } \\
\text { Development (WBCSD) }\end{array}$ & $\begin{array}{l}\text { 'Knowledge is the factor that leads us to change our way of thinking. However, it is the } \\
\text { understanding that leads to change attitudes. The IYGU puts emphasis on culturally } \\
\text { different paths to global sustainability. And that only changing individual action will } \\
\text { lead to change of collective action whose result will be the improvement of the } \\
\text { system in global scope.' }\end{array}$ \\
\hline $\begin{array}{l}\text { Professor Klaus Toepfer (Germany) } \\
\text { Former Executive-Director of UNEP, Director of } \\
\text { Institute for Advanced Sustainability Studies (IASS) }\end{array}$ & $\begin{array}{l}\text { The fall of the Berlin Wall was the crucial symbol of overcoming the bipolar world. } \\
\text { 'Now more than ever it is vital to the globalization process that we find the strength } \\
\text { time and again to alsounderstand and relate to the positions, thoughts, and } \\
\text { expectations of others and seek dialogue instead of confrontation. Furthermore, it } \\
\text { will be important to advance the quest for solutions that do not challenge one's own } \\
\text { inalienable values while also granting this privilege to others.' }\end{array}$ \\
\hline $\begin{array}{l}\text { Professor Gordon McBean (Canada) } \\
\text { Nobel Prize Laureate for Peace (IPCC), President of } \\
\text { ICSU and Council for Future Earth }\end{array}$ & $\begin{array}{l}\text { 'The IYGU is very important in building societal understanding, enabling actions to } \\
\text { face the risks posed by global environmental change. It is seizing opportunities in } \\
\text { transitions to global sustainability and is providing a critical start for a successful } \\
\text { Future Earth Programme.' }\end{array}$ \\
\hline $\begin{array}{l}\text { Professor Anthony Giddens (UK) } \\
\text { Member of the House of Lords and former Director } \\
\text { of the London School of Economics }\end{array}$ & $\begin{array}{l}\text { We live in the most interconnected world in history. Yet at the same time that world is } \\
\text { riven by conflicts, dislocations and uncertainties - an unsettling and disturbing } \\
\text { mixture of huge opportunities and existential risks. Finding a positive balance will } \\
\text { demand fundamental intellectual rethinking and new forms of collaboration of the } \\
\text { sort the IGYU offers'. }\end{array}$ \\
\hline $\begin{array}{l}\text { Professor Yuan Tseh-Lee (Taiwan) } \\
\text { Nobel Prize Laureate in Chemistry (1986) }\end{array}$ & $\begin{array}{l}\text { Sustainable development is a global challenge, but solving it requires transforming } \\
\text { the local - the way each of us lives, consumes, and works. While global negotiations } \\
\text { on climate attack the sustainability crisis from above, the IYGU complements them } \\
\text { beautifully with coordinated solutions from below - by getting individuals to under- } \\
\text { stand and change their everyday habits. This twin approach elevates our chance of } \\
\text { success against this crisis, the gravest humanity has ever seen.' }\end{array}$ \\
\hline
\end{tabular}


everyday (best) practices.

3. Enhance awareness of the individual capacity and responsibility for everyday decision-making.

4. Produce school teaching modules and study guidelines to be implemented at all educational levels - from primary to tertiary and post-experience education.

5. Serve as a catalyst for transdisciplinary cooperation and improve the culturally differentiated transfer of scientific insights into social practice and vice versa.

The IYGU program focuses on three interfaces and is a threefold bridge-builder:

$\begin{array}{lll}\text { Local } & \| & \text { Global } \\ \text { Social } & \| & \text { Natural } \\ \text { Everyday } & \| & \text { Science }\end{array}$

The envisaged complementation of the Future Earth initiative includes the bottom-up mobilization of social and natural scientists, as well as scholars of the humanities, to engage in sustainability research from their specific perspectives. This will enhance the opportunities for citizens and decision-makers to benefit from and relate to new research findings and orientations. Finally, the IYGU will advance science and technology in terms of sustainable development and contribute to achieving the United Nation's Post2015 Development Agenda.

The IYGU will bridge the gaps between:

- different realms of the world of science;

- science and everyday worlds;

- different cultural realms of the global society.
The IYGU action plan involves three core elements: research, education, and information. In all three fields, the IYGU focuses on habitual day-to-day practices and seeks to shed light on their embeddedness in biophysical and socio-cultural contexts, as well as on the ways in which such everyday practices link the local and the global scale (Fig. 2). In this way, the IYGU's actions will highlight the importance of culturally differentiated ways to address the needs of society. On the whole, the IYGU intends to support new geographical imaginations for new geographical realities in the globalized digital age.

In the field of research, the IYGU will:

- bring together social and natural scientists as well as the humanities to gain an understanding of the global impacts of everyday activities;

- take the logic of everyday activities into account when developing research questions or programs;

- show culturally differentiated pathways towards global sustainability.

In the field of education, the IYGU will encourage teaching institutions at all educational levels to engage in transdisciplinary teaching for global sustainability, namely building experience approaches that bridge academic knowledge and individual perceptions (Carbone et al., 2012). It will contribute to the establishment of such educational programs and encourage the use of the relevant research results at all educational levels in classrooms and at universities throughout the world.

Information will be provided in cooperation with strong partners from the media to increase public awareness by using, for example,

\section{IYGU preparation Activities}

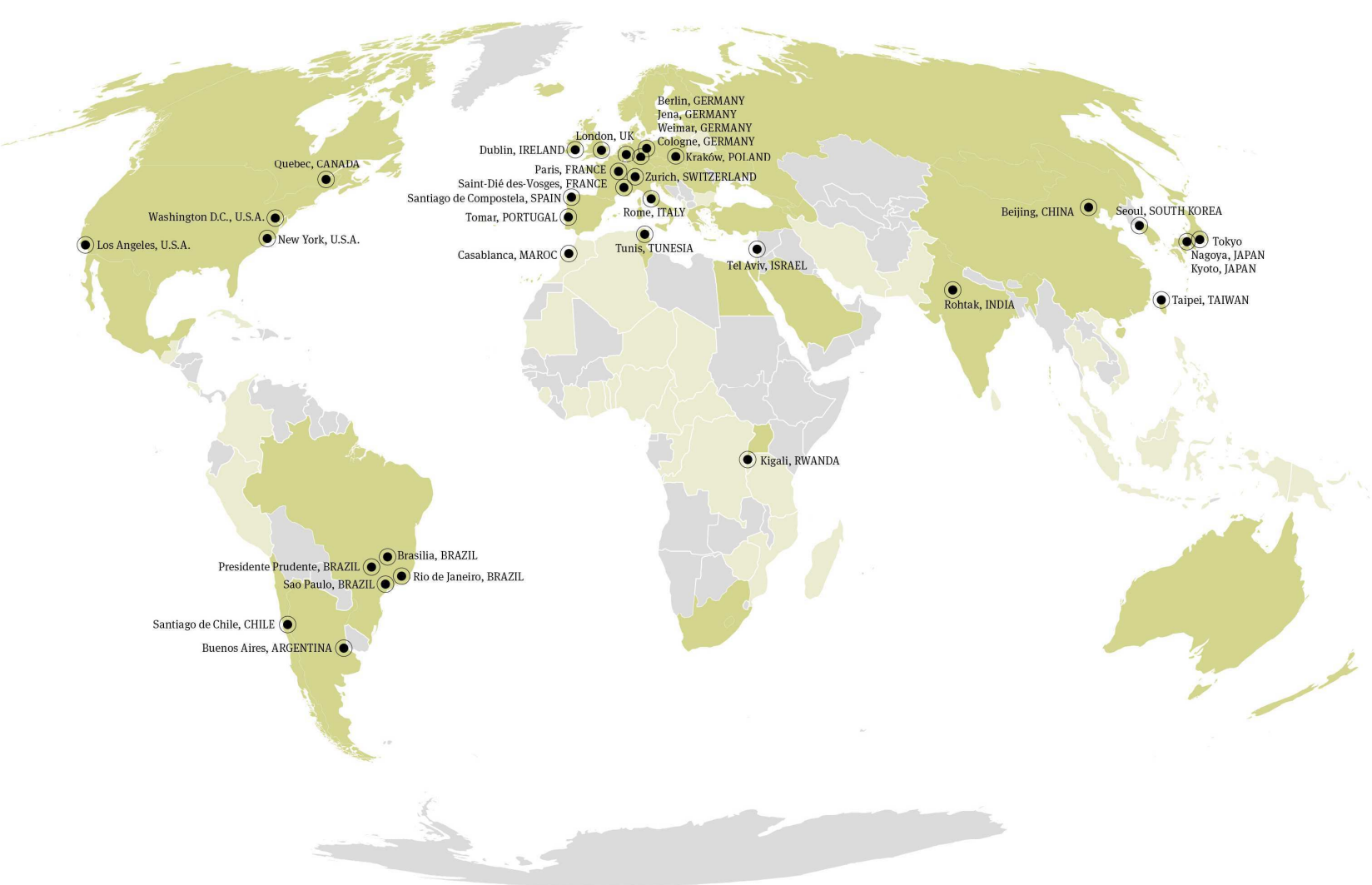

Figure 2. Main places where the IYGU is being promoted. 


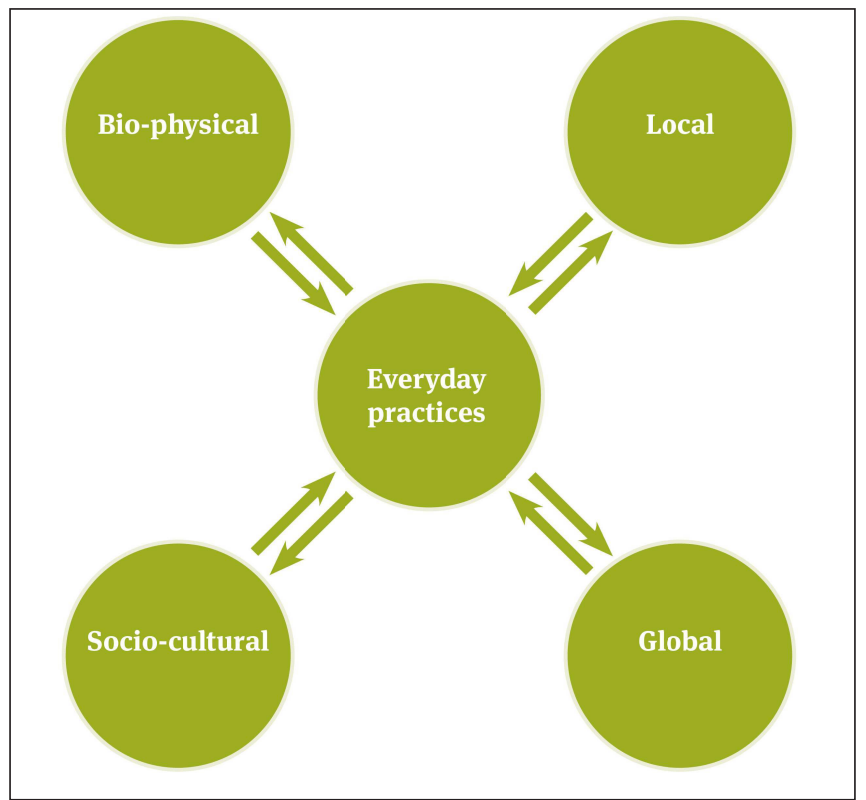

Figure 3. Core dimensions of everyday practices.

print media, computer games, social networks, Internet platforms (www.global-understanding.info), and TV programs.

\section{Topical Framework and the Outreach Program}

The topical framework for the IYGU action in the three mentioned fields and implemented by the IYGU Regional Action Centers around the world is delivered by six basic publication as Springer Briefs on a set of everyday actions produced by everyone everywhere every day. These publications as IYGU Springer Briefs will highlight the two-fold embeddedness of human activities in bio-physical and sociocultural processes at the global and local levels and focus on needs identified in the Post-2015 Development Agenda. The brochures will provide suggestions for conference topics and research proposals and projects, teaching and study programs as well as general information

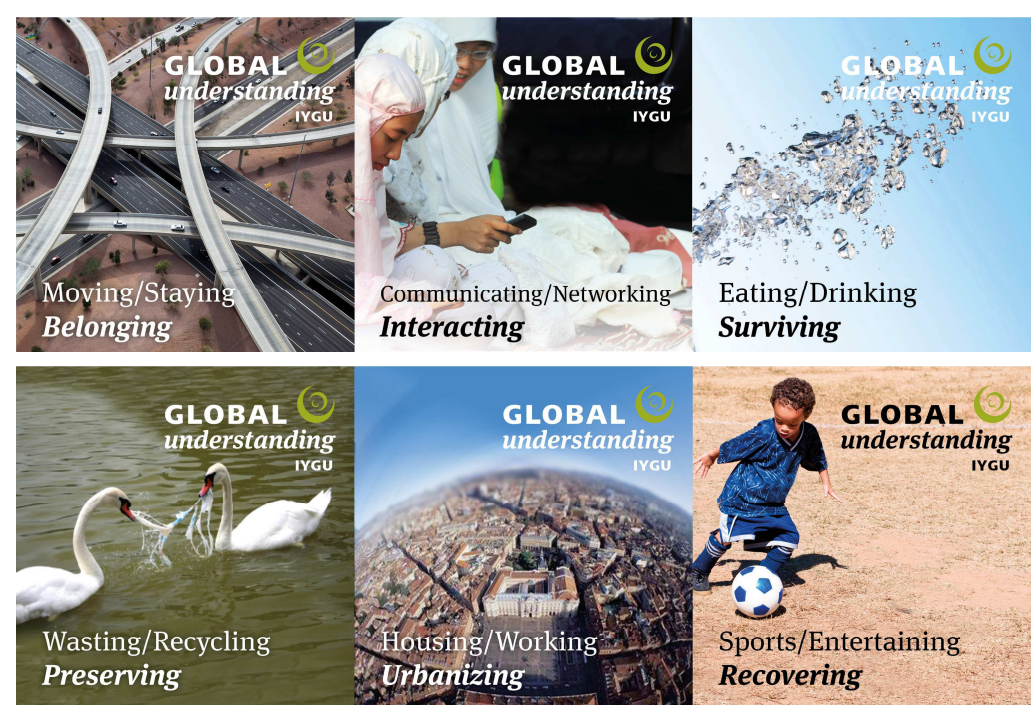

Figure 4: The six open access publications - each with a triple focus - will address everyday behavior in thelight of the post-2015 Development Agenda, the connections between the global and the local, and actions to improve global. for the media, press, and the Regional Actions Centers (RAC). In the preparatory period (2015) for the IYGU, the RAC will translate these brochures in the dominant languages spoken in their region, as done before in similar global initiatives, like the International Year of Planet Earth during the triennium 2007-2009 (Mulder et al., 2006; Henriques et al., 2010).

Thematic publications will be on the following six topics: Eating/ drinking//surviving (Jackson, 2015;Sultana and Loftus, 2011), Moving/staying//belonging (Kingsley and Urry, 2009),Working/ housing//urbanizing (Scott, 2014; Taylor and Derudder, 2015;Pickles and Smith, 2016), Communicating/networking//interacting (Castelles, 2009; Robertson, 2016), Wasting/recycling//preserving, Sports/ entertaining//recreating (Fig. 4).

These six book publications - each with a triple focus - will address everyday practices in the light of the UN Post-2015 Development Agenda. During the first part of the IYGU in 2016, these brochures will summarize relevant current knowledge. A second set, produced after the IYGU, will evaluate, collect, and promote the results in research, teaching, and information.

National learned societies, ministries of education, culture, science and technology, educational institutions, and non-governmental, as well as governmental organizations, will plan and implement the IYGU activities. More than 50 Regional Action Centers and the Global Secretariat in Jena (Germany) will coordinate these activities. Over the course of 2016, each Regional, and perhaps also each National Center, will present 366 ways to reach global sustainability - 366 culturally specific solutions, one example every day of a best practice, made accessible to as many people as possible in as many regional contexts as possible (Fig. 5).

In the process of building the IYGU initiative, the network has grown strong with global partners and alliances. These partnerships that have evolved over time provide a solid basis for further development of the IYGU initiative.

\section{Coordination and Partners}

The IYGU was initiated by the International Geographical Union (IGU), which remains an important partner (Fig. 6). The IGU has 57 full national members and 40 associate national members with observer status. At their General Assembly in Cologne in August 2012, the presidents of the national committees and the IGU Executive Committee unanimously approved the IYGU initiative for 2016.

The three global scientific umbrella organizations that jointly proclaimed the 2016 IYGU in September 2015 are encompassing most of the important domains of research. The International Council for Science (ICSU) currently has 31 Scientific Union Members and 120 National Scientific Members covering 140 countries (Fig. 7). The International Social Science Council (ISSC) represents 17 Associations and Unions, 34 Member Organizations, which are mainly national funding organizations, and 10 Associate Members from more than 100 countries. The International Council of Human Sciences and Philosophy (CIPSH) represents international unions/committees of 16 disciplines and a large number of national academies, covering 154 countries.

In total, the network of these three international scientific umbrella organizations comprises international unions/organizations of about 60 disciplines in more than 

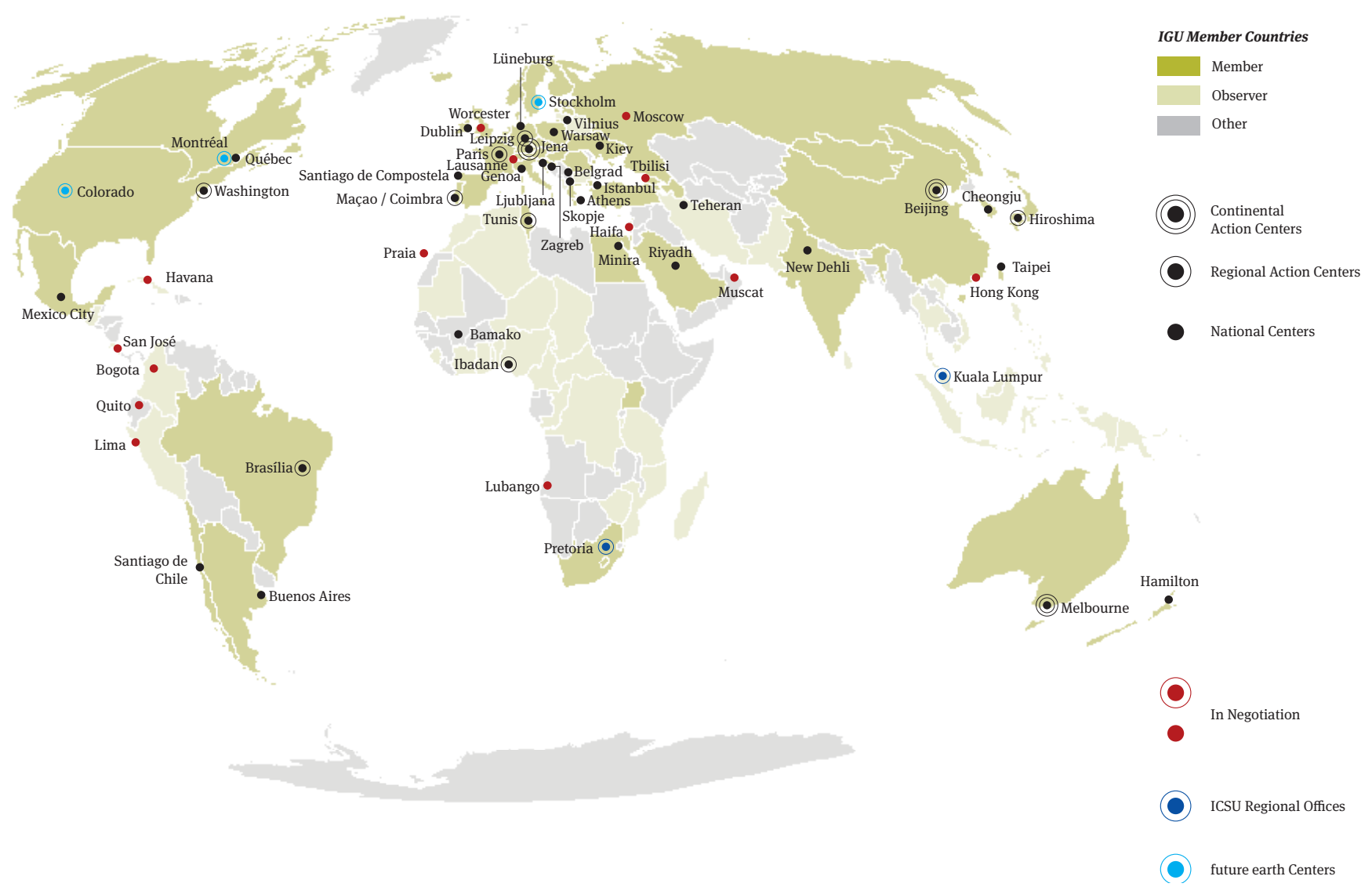

Figure 5: Network of IYGU Regional Action Centers, IGU Member Countries, ICSU Regional Offices and Future Earth Centers by October, 2016.

\section{World Map of IGU Members Countries}

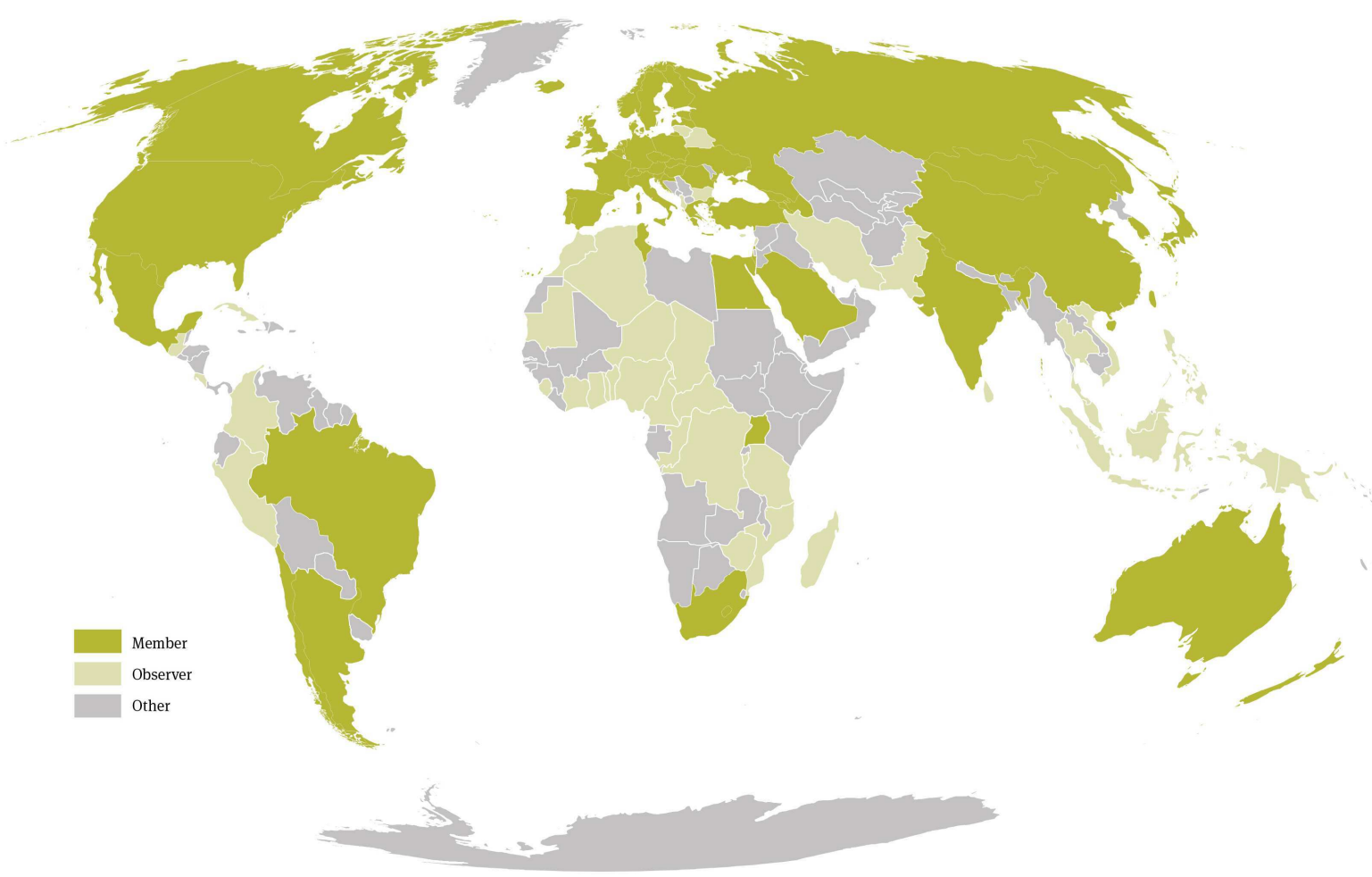

Figure 6: World Map of IGU Member Countries. 


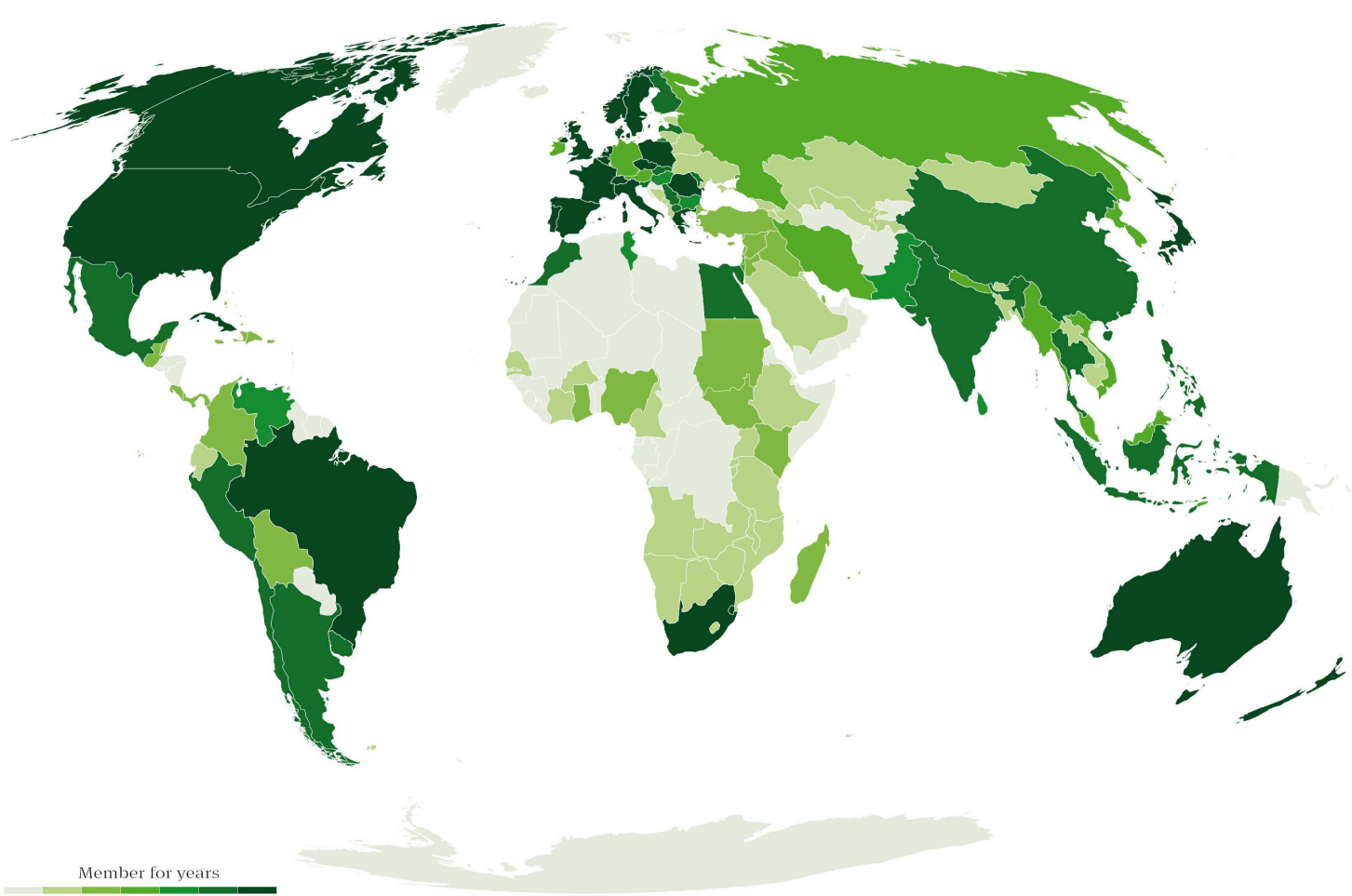

Figure 7: World Map of ICSU Members.

150 countries, representing a community of more than 3,500 national disciplinary organizations.

The IYGU is partnering the Future Earth initiative, co-sponsored by ICSU, ISSC, UNESCO, UNEP, UNU, and the Belmont Forum.

The IYGU is cooperating with a large group of partners to highlight the role of the cultural, social, and natural sciences in the quest for global sustainability arrived at through culturally differentiated ways and addressing the needs of various societies by proposing new geographical imaginations for new geographical realities, and globalized everyday worlds.

The list of IYGU supporters also includes the:

- International Geographical Union (IGU)

- International Council of Science (ICSU)

- International Social Science Council (ISSC)

- International Council for Philosophy and Human Sciences (CIPSH)

- Future Earth Initiative of ICSU and ISSC

- World Humanities Conference Liège 2017 (under the auspice of CIPSH and UNESCO)

- Association of American Geographers, whose representatives also initiated cooperation with National Geographic and its various print and audiovisual media channels, and potentially also the U.S. National Academy of Sciences

- International Union of Geodesy and Geophysics (IUGG)

- International Union of Geological Sciences (IUGS)

- International Federation of Rock Art Organization (IFRAO)

- Brazilian Chamber of Industry (CNI)

- UNESCO \& Ministry of Foreign Affairs of the Republic of Korea Initiative for Global Citizenship Education for Sustainable Development

- Local Organizing Committee of the Olympic and Paralympic Games Rio de Janeiro 2016 and the Sustainability and Legacy Commission of the International Olympic Committee (IOC)
- Science and Technology in Society Forum (STS)

- National Committee for Environmental Law, an agency of the Federal Council of Ordem dos Advogados do Brasil (Brazilian Bar Association)

- APHELEIA, Erasmus+ strategic partnership for Cultural Integrated Landscape management, including 18 European universities, research institutions and public authorities, in 8 European Union countries

- Morro de Pilar Declaration for Local Sustainability and Global Understanding (Belo Horizonte, Brazil)

- CSR Research Foundation New Delhi

- DFG Deutsche Research Foundation

- Friedrich-Schiller-University of Jena

- Max Plank Institute BioGeoChemistry

- Graduate School Human Behaviour in Social and Economic Change (GSBC)

- Shockwave Festivals

From the private sector, it includes:

- Katerva

- ESRI

- Ernst Abbé Foundation

- Homeward Bound Project (DATTNER GRANT PTY LTD)

\section{Organizational Structure}

The Organizational Structure of the IYGU is coordinated by the Executive Director who is assisted by a steering committee and a scientific board on the articulation actions with the RACs and on the implementation of outreach, media and education activities (Fig. 8). RACs adopt locally significant structures that are capable of implementing the objectives of the Year and of disseminating their outputs through social networks and/or official websites. The Regional Action Center for Western Europe (Mação/Coimbra) and the Athens 


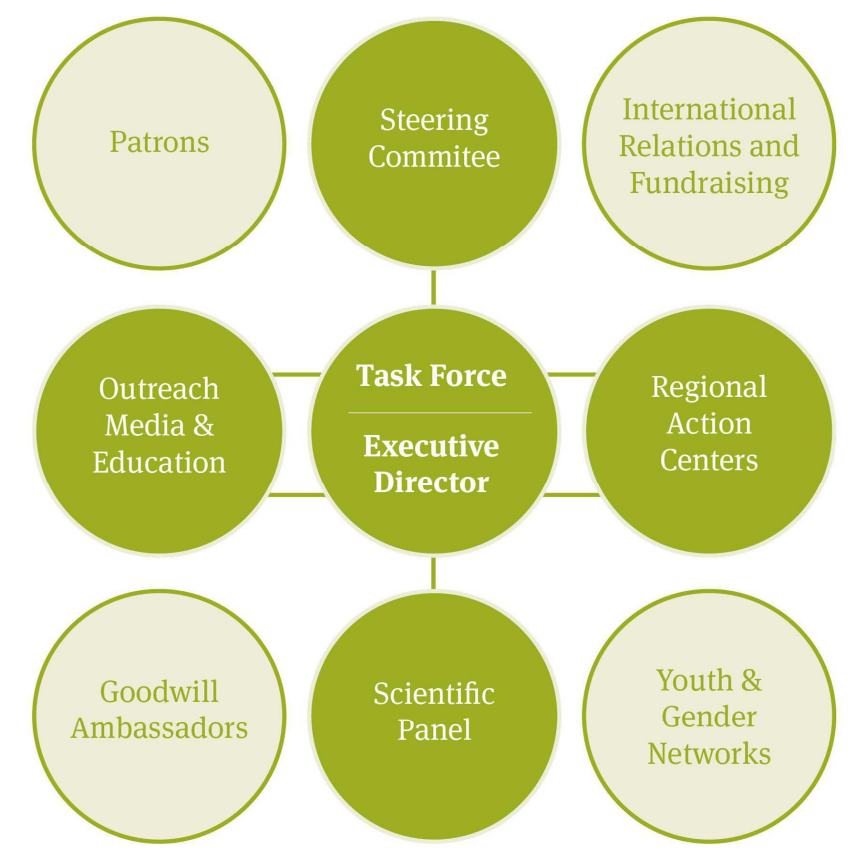

Figure 8: The organizational structure of the IYGU

Regional Action Center use websites (http://www.entendimentoglobal. ipt.pt/ and http://iygu.ntua.gr/, respectively); the Regional Action Center for Brazil and Latin America uses a social network (https:// www.facebook.com/iyguamericalatina/?fref=ts).

\section{Final Remarks}

It is expected that the IYGU Outcomes will represent relevant contributions to several global institutions and initiatives. The IYGU addresses key UN Charter Constitution issues as it aims to strengthen international co-operation by preparing new strategies to face global challenges. Better global understanding supports economic, social, cultural and humanitarian co-operation. The IYGU's new level of goal-driven scientific cooperation will produce advanced educational modules which will contribute to promote practical routes towards a global understanding of the cultural and social implications of new geographical living conditions and new global realities, a major goal of the UNESCO.

Several past and ongoing global initiatives may also be favored by the IYGU actions as the framework of the IYGU contributes to the ICSU-ISSC Future Earth initiative and seeks to support the implementation of the Rio+20 Declaration. Moreover, the IYGU will complement the outcomes of the UN Decade of Education for Sustainable Development (ESD) 2005-2014 with a focus on practical ways of introducing its key results into everyday practices and will provide sustainability education and public information, establishing processes for embedding the ESD's principal results in future generations' routines.

And finally, the IYGU will draw on and promote findings of other UN International Years, namely the IY of Mountains (2002), the IY of Freshwater (2003), the IY of Planet Earth (2008) and the IY of Biodiversity (2010).

\section{Acknowledgments}

The authors acknowledge the support from the International
Geographic Union, the three international councils for sciences (ICSU, ISSC and CIPSH), the University of Jena (Germany), and the funds from FEDER through the Competitiveness Factors Operational Programme - COMPETE and national funds by FCT (Portugal) in the frame of the UID/Multi00073/2013 project. Thea authors are grateful to Dr. Jose Pedro Calvo and to Dr. Eduardo de Mulder for the careful revision of the manuscript.

\section{References}

Albrow, M., 1996, The Global Age: State and Society Beyond Modernity. Cambridge, Polity Press.

Almeida, N., Ferreira, C., Allué, E., Burjachs, F., Cruz, A., Oosterbeek, L., Rosina, P. and Saladié, P., 2014, Acerca do impacto climático e antropozoogénico nos inícios da economia produtora: o registo do Alto Ribatejo (Portugal central, oeste da Peninsula Ibérica). In: Arquafauna e paisagem, Brasil Habilis Press, pp. 63-84.

Beck, U., 2016, The Metamorphosis of the World: How Climate Change is Transforming Our Concept of the World, London, John Wiley and Sons.

Bunders, J.F.G., Bunders, A.F. and Zweekhorst, M.B.M., 2015, Challenges for Transdisciplinary Research, In: B. Werlen (Ed.), Global Sustainability. Cultural Perspectives and Challenges for Transdisciplinary Integrated Research, Dordrecht, Springer Publishers, pp. 317-50.

Carbone, F., Oosterbeek, L. and Costa, C., 2012, The educational and awareness purposes of the Paideia approach for heritage management. Nat. Hazards Earth Syst. Sci., vol. 12, pp. 1983-1986.

Castelles, M., 2009, The Rise of the Network Society: The Information Age: Economy, Society, and Culture. London, John Wiley and Sons.

Cruz, A.R., Miliken, S., Oosterbeek, L. and Peretto, C. (coord.), 1999, Human Population Origins in the Circum-Mediterranean Area: Adaptation of the Hunter-Gatherer groups to environmental Modifications, série ARKEOS, vol.5, Centro Europeu de Investigação da Pré-História do Alto Ribatejo.

Henriques, M.H., Guimarães, F.A., Sá, A.A., Silva, E. and Brilha, J., 2010, The International Year of Planet Earth in Portugal: past activities and further developments, Episodes, Vol. 33, no. 1, pp. 33-37.

Jackson, P., 2015, Food Words, London, Bloomsbury Publishing Plc.

Kingsley, D. and Urry, J., 2009, After the Car, Cambridge, Polity Press.

Mulder, E.F.J., De, Nield, T. and Derbyshire, E., 2006, The International Year of Planet Earth (2007-2009): Earth Sciences for Society, Episodes, v. 29, no. 2 , pp. $82-86$.

O’Brien, K., Reams, J., Caspari, A., Dugmore, A., Faghihimani, M., Fazey, I., Hackmann, H., Manuel-Navarrete, D., Marks, J., Miller, R., Raivio, K., Romero-Lankao, P., Virji, H., Vogel, C. and Winiwarter, V., 2013, You say you want a revolution? Transforming education and capacity building in response to global change, Environmental Science \& Policy, Vol. 28, pp. 48-59.

Osterbeek, L., Scheunemann, I. and Santos, L., 2013, Water resources and human behaviour: an integrated landscape management perspective. Cadernos do LEPAARQ, vol. X, nº 20, pp. 27-242.

Pickles, J. and Smith, A., 2016, Articulations of Capital: Global Production Networks and Regional Transformations, London, John Wiley and Sons.

Robertson,M. (ed.), 2016, Communicating/networking//interacting, Springer, Heidelberg.

Rosa, H., 2015, Social Acceleration, New York, Columbia University Press.

Scott, A., 2014, A World in Emergence: Cities and Regions in the $21^{\text {st }}$ Century, London, Edward Elgar Publishing.

Stehr, N., 2016, Exceptional Circumstances. Does Climate Change Trump Democracy?, Issues in Science and Technology, National Academies of Sciences, Engineering, and Medicine, National Academy Press, Dallas, pp. 37-44.

Sultana, F. and Loftus, A., 2011, The Right to Water, London Taylor and Francis Ltd.

Taylor, J. P. and Derudder, B., 2015, World City Network: A Global Urban Analysis. London, Taylor and Francis Ltd. 
Werlen Benno (Ed.), 2015a, Global Sustainability. Cultural Perspectives and Challenges for Transdisciplinary Integrated Research, Dordrecht, Springer Publishers.

Werlen, B., 2015b, From Local to global Sustainabilty: Transdiciplinary

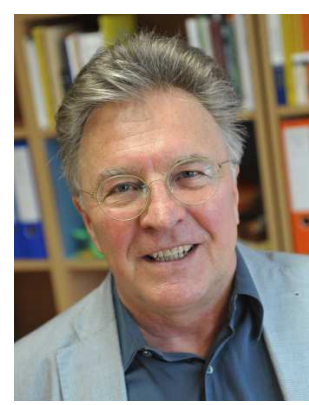

Benno Werlen is currently a professor of Social Geography at the Friedrich-Schiller University Jena in Germany. He is the Executive Director of the IGU Initiative for an International Year of Global Understanding, which links the major scientific global umbrella organizations' efforts to achieve global sustainability. Benno Werlen has been a visiting scholar at the University of Cambridge (Kings College), and at the London School of Economics and the University of California at Los Angeles (UCLA). From 2008-2015 he was a member of the European Research Council in Brussels in the field of Society \& Environment, and from 2008-2012 of the French ANR

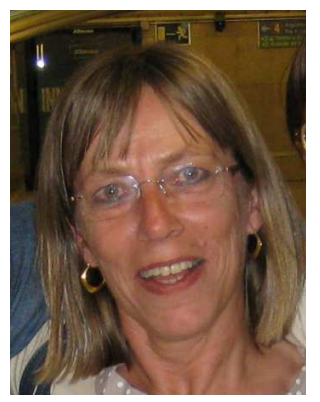

Maria Helena Henriques is Professor at the Earth Sciences Department of the Faculty of Sciences and Technology of the University of Coimbra (Portugal) and Researcher of the Geosciences Centre of the same University. Graduated in Geology and in Journalism, PhD and ScD in Palaeontology and Stratigraphy by the University of Coimbra, she was guest professor in several European, African and Brazilian Universities. She is the Convenor of the Aalenian Working Group of the International Subcommission on Jurassic Stratigraphy (ICS, IUGS), integrates the Portuguese Committee for the International Geoscience Programme (IGCP) and coordinates the Regional Action Centre of Western Europe (Mação/Coimbra) for the International Year of Global Understanding.
Integrated Research in the Digital Age, In: B.Werlen (Ed.), Global Sustainability. Cultural Perspectives and Challenges for Transdisciplinary Integrated Research, Dordrecht, Springer Publishers, pp. 316.

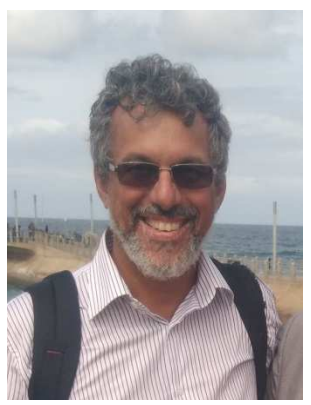

Luiz Oosterbeek is a graduate in History and PhD in Archaeology, and pursues research in archaeology, heritage and landscape management in Portugal, Africa and Southern America. He is the SecretaryGeneral of the International Council for Philosophy and Human Sciences and of the International Union of Prehistoric and Protohistoric Sciences. Professor at the Polytechnic Institute of Tomar (Portugal), he is member of the Scientific Council of the National Museum of Natural History in France and guest Professor in several European and Brazilian Universities. He is currently President of the Instituto Terra e Memória, researcher of the Geosciences Centre of Coimbra University and VicePresident of HERITY International. 